\title{
Re-conceptualization of Business Model for Marketing Nowadays: Theory and Implications
}

\author{
Ahmad FIRMAN', Aditya Halim Perdana Kusuma PUTRA², Zainuddin MUSTAPA², \\ Gunawan Bata ILYAS ${ }^{4}$, Kasnaeny KARIM ${ }^{5}$
}

Received: April 07, 2020 Revised: May 03, 2020 Accepted: June 07, 2020

\begin{abstract}
This study aims to develop the concept of innovation models with the marketing channel construct approach, marketing innovation, product segmentation, and customer insight; as well as improvements to the theory of resource-based combined with the method of service-dominant logic. This study approach is based on quantitative descriptive conducted with three stages of testing scenarios. The first test is the mapping of the innovation model construct through testing the validity and reliability with the moderation of customer orientation variables. The second scenario examines the relationship of influence between the independent variables on the dependent variable of 29 hypothetical analysis equation modeling. The unit of analysis was conducted on 497 SMEs involved in the food and beverage sectors, with the criteria being SMEs must have a rating of 4-5 points on the Go-Food applications software. The results shown that: 1) the construct used to develop an innovative model both directly and via moderation is positive and significant; 2) Through a complicated relationship that involves all components of the variable, it outlines a positive and significant effect except for the path of analysis ( $\mu 5)$. The theoretical and managerial implications state that the service-dominant logic approach and resource-based view theory have extreme reliability and interrelations.
\end{abstract}

Keywords : Innovation, Business Strategy, Service-Dominant Logic, Resource-Based View, Competitive Advantage

JEL Classification Code: M20, M31, O32, 036

\section{Introduction}

The business environment continues to experience very significant changes along with the development of technology, so that patterns and systems that are commonly

\footnotetext{
${ }^{1}$ First Author and Corresponding Author. Associate Professor, Magister of Management, STIE Nobel Indonesia, Makassar, Indonesia [Postal Address: Jl. Sultan Alauddin Number-212, Makassar City, South-Sulawesi, 90231, Indonesia] Email: firman.nobel53@gmail.com

${ }^{2}$ Assistant Professor, Faculty of Economics and Business, Department of Management, Universitas Muslim Indonesia. Email: adityatrojhan@gmail.com

${ }^{3}$ Assistant Professor, Postgraduate Program, Department of Public Administration, Universitas Bosowa, Makassar, Indonesia.

${ }^{4}$ Assistant Professor, Department of Management, STIE AMKOP, Makassar. Indonesia

() Copyright: The Author(s)

This is an Open Access article distributed under the terms of the Creative Commons Attribution Non-Commercial License (http://Creativecommons.org/licenses/by-nc/4.0/) which permits unrestricted noncommercial use, distribution, and reproduction in any medium, provided the original work is properly cited.
}

used are not enough to be a guarantee that the business will last forever. New approaches are needed to overcome every problem that immediately arises and is unique. In business, risks and opportunities come almost simultaneously; it is even tricky to guess whether it is risk inactivity or an opportunity, which can then be used as a stepping-stone in gaining profits and achieving goals in the industry. Innovative approaches are needed that are more measurable and clear. Indeed, the presence of the Internet and the development of marketing channels must be able to become a new vehicle for business people to be able to gain a broader market share.

Grover, Agrawal, and Khan (2004) argue that innovation is one way for companies to be able to survive. Innovation is the reason for differentiation between competitors, and innovation also makes a striking difference regarding product quality (Yusuf \& Putra, 2019; Firman et al., 2020). Felício, Caldeirinha, and Dutra, (2019) also affirm that innovation will increase the company's ability and competitive advantage, which in turn will have an impact on company performance. Innovation is a technological, managerial, and social process, in which new ideas or 
concepts are first introduced to be put into practice in the culture, are determining factors in industrial competition, and are formidable weapons against the competition (Raja \& Wei, 2014; Aujirpongpan \& Hareebin, 2020).

Innovation contains two components of capability, namely, the ability to explore innovation, meaning that change is carried out through exploration or search to discover something new, and the ability to innovate through improving the quality of products in the form of goods or services that have been created (Alpkan, Şanal, \& Ayden, 2012). The era of innovation is developing, along with the development of market competition strategies. Lusch et al. (2007) extend the concept of service-dominant logic (SD logic) as an effort to improve services to consumers. The idea developed by Lusch et al. (2007) is to prioritize the creation of values rather than size. The concept of SD logic implies some integration to create value-added for consumers, including the role of business people, integration of resources, services, cooperation between elements of institutions, and forms of environmental stewardship. Departing from this, the theory of service-dominant logic is the right choice to develop the concept of innovation in this study. They were also departing from the many criticisms about resource-based view to achieving competitive advantage. Porter (1985) considered this view less than optimal if it only presents the competitive advantage model approach without measuring the costs. Therefore, in this study, a change in the measurement of the concept of competitive advantage that was coined by Porter in 1985 was to propose a manifest cost-efficiency variable that must be in line with the improvement in the quality of production of a product.

This study addresses several research questions, including 1) whether the development of conceptual models using the construct of marketing channels, innovation capabilities, insights on product segmentation as well as business insights towards customers from a Service-Dominant Logic perspective can be a valid and reliable variable for future innovation concepts; 2) whether the idea that has been developed can improve the empirical relationship to competitive advantage.

\section{Literature Review}

Sustained competitive advantage has been a significant theme of research in strategic management since the 1960s (Agarwal \& Goodstadt, 1997; Brouthers \& Brouthers, 1997; Roberts, 1998; Annarelli, Battistella, \& Nonino, 2020; Liu, Jiang, \& Zhao, 2019). The framework used to achieve sustainable competitive advantage is to carry out strategies that maximize internal strength through the exploitation of opportunities in the external environment, neutralize threats from the external environment, and minimize internal weaknesses in the company. Most of the research on management strategies focuses on opportunities, threats, strengths, and weaknesses, and the compatibility between the four (Dahliah et al., 2020). However, most study places more emphasis on analyzing opportunities and risks of the external environment rather than internal company analysis (Leigh, 2010; Haming et al., 2019). The popular concept used is the five-force model from Porter and Advantage (1985). Porter's theory emphasizes that the company's opportunities will be higher, and the threats will be reduced if the company operates in an attractive industry. There are two main assumptions used in this concept. Firstly, the resources owned or strategies carried out by the company in a trade or a strategic group are homogeneous. Secondly, the resources used to implement the strategy have high mobility. With the versatility of resources, heterogeneity of support will not last long because these resources will be readily obtained and owned by other companies in one industry or strategic group.

Discussion of the characteristics of resources that can be a source of sustainable competitive advantage for the company. Barney (1991) explicitly reviewed critically the assumption of homogeneity and mobility of support in one industry. This assumption is the foundation of the fiveforce model with an industrial organization perspective. Barney (1991) also stated that companies could not achieve sustainable competitive advantage if resources can be distributed to various companies and have high mobility in one industry or strategic group. Implementing strategies requires specific resources. Based on the homogeneity assumption, it means that all companies in one sector have the same resources. That is, companies can carry out the same strategy, so that under these conditions, the company will not achieve sustainable competitive advantage because all companies will achieve the same performance.

Other than that, Barney (1991) also criticized the concept of barriers to entry, which would not be possible if the company's resources in one industry were identical with high activity mobility. If the company has specific resources and competitors in one sector also have the same resources, these resources are likely to have other competitors, then the competition has no obstacles. Conversely, if companies have specific and unique resources and other companies have different resources, then these resources cannot be spread across various companies. Barriers to entry will be created with the assumption that heterogeneous resources and imperfect mobility will create obstacles. The primary substance of the resource-based view is resources that can produce sustainable competitive advantages, namely, resources that are valuable, rare, unique, difficult to imitate, and have no substitutes. Several studies have examined the relevance of RBV to the innovation aspect as part of competitive advantage (Distanont \& Khongmalai, 2018), which states that innovation increases profits in the competition through external factors. These external factors 
are divided into two groups: micro-oriented factors and macro-oriented factors (Ho et al., 2017). The results of their research on aspects of the value chain in agriculture indicate that there is no significant relationship between market orientation and performance. However, customer orientation and coordination between functions are positively related to innovation, having a positive correlation between applying innovation to financial performance.

Findings from Ho et al. (2017) provide insight into the relationships between market orientation, innovation, and performance in agricultural value chains in developing countries. Abdolmaleki and Ahmadian (2016); Ruiz-Ortega et al. (2017); and Elrehail (2018) stated that the purpose of innovation through the development of new products is a tactical and systematic effort of the company to respond to customer needs, meeting aspects of the organization's consistency, the existence of market conditions, environmental changes, increasing profits, customer satisfaction, and overcoming competitor policies. Alpkan, Şanal, and Ayden (2012); Giao, (2020); Le (2020); and Tran, Vo, and Dinh (2020) also justify the relevance of innovation associated with aspects of the RBV, defined as an expression of market orientation and innovation strategy as a form of developing ambitious organizations.

Innovation is a broader concept that addresses the application of new ideas, products, or processes. Innovation is a corporate mechanism to adapt in a dynamic environment (Vila, Bharadwaj, \& Bahadir, 2015; Alam et al., 2019; Halim et al., 2019; Chiu \& Lin, 2019). Therefore, companies are required to be able to generate new thoughts, new ideas, and offer innovative products and service improvements that satisfy customers. Innovation is defined as the process and results of developing the use or mobilization of knowledge, skills (including technology skills) as well as experience to create or improve products (goods or services). Innovation is also the result of a new process or system that provides significant value to economic and social aspects. Innovation has fourmain characteristics. First, it has a specificity, meaning that change has distinctive features such as ideas, programs, order, systems, including the possibility of expected results (Chung \& Tan, 2017). Second, it has a characteristic or novelty (D'Este et al., 2016). This means that innovation must have characteristics as work and thought that have a degree of originality and novelty. Third, the innovation program is implemented through a planned schedule (Rodríguez et al., 2020; Abdelaal, 2019; Mappamiring et al., 2020). It means that innovation is carried out through a process that is not rushed, but innovation activities are prepared carefully with a clear program that is planned. Fourth, the change that was rolled out had a purpose (De Silva, Al-Tabbaa, \& Khan, 2019). It means that the innovation program carried out must have the direction to be achieved, including the leadership and strategy for achieving that goal.
Grover, Agrawal, and Khan (2004) state that innovation is one way for companies to be able to survive. Innovation is the reason for differentiation between competitors, and change also makes a striking difference regarding product quality. (Indahingwati et al., 2019; Merdika et al., 2019). Felício, Caldeirinha \& Dutra, (2019) also affirm that innovation will increase the company's ability and competitive advantage, which in turn will have an impact on company's performance. Innovation is a technological, managerial, and social process, where new ideas or concepts are first introduced to be put into practice in a culture, are a determining factor in industrial competition, and are a formidable weapon against the competition (Raja \& Wei, 2014). Ioanid, Deselnicu, \& Militaru, (2018) in their research, use a model approach that has been developed by Schmoklers about innovation. He states that innovation can be supported through the use of technology. Furthermore, Ionaid et al. (2018) measure innovation on several important aspects such as the application of the latest marketing ideas in the modern business world, the development of new designs, knowledge of business, and integrated management governance, R\&D capabilities to the effort of sharing and involving employees (Share of the employee) as a form of maximizing the application of innovative ideas.

Putra et al. (2019) and Mashur et al., (2019) present several measurements of the dimensions of innovation: 1) Focusing attention and seeking overall improvement in aspects of marketing channels (marketing channels), where the business is to rely on in meeting aspects of customer needs, the ability of business providers to use technology tools to increase sales on digital e-commerce based sales, and the ability to repeat and focused advertising. 2) The strength of business providers to use social media as a medium for sales and promotion. 3) The use of endorsement strategies to be more convincing for the products being marketed. 4) Capability and reliability innovations from the marketing aspect through capacity building include the ability of entrepreneurs and internal business in mastering the products being marketed, and the ability to conduct periodic evaluations of the achievements of the products being sold. 5) The ability to educate customers. 6) Ability and clarity in product segmentation for consumer strata, which include age, gender, and income level. 7) In-depth capabilities regarding customer insight, which means ability oriented to development over times, protection and security of user data, selection of the best raw materials, good quality control before selling on the market, and excellent service and after-sales that do not confuse consumers.

Ionaid et al. (2018) found that the concept of marketing in the 4.0 era emphasized the production process, not only based on access to quantity and quality of products, but also interconnections involving internal and external parties of a business through optimizing the time and cooperation that 
was developed between domestic and foreign companies, in this case, prospective customers as an end-user (Ioanid et al., 2018; Mashur et al., 2019; Mashur et al., 2020). Limaj and Bernroider (2019) emphasize that innovation performance is measured in two main ways, namely, Explorative Innovation and Exploitative Innovation, where the indicators used include the ability of organizations to realize products and services that are in line with consumer expectations, new product innovations, and continuous improvement in service aspects, using their products within the internal company as an effort to build advocacy for other consumers, try all positive opportunities and try to enter a broader marketing channel (Marketing Channel) such as e-commerce, maximizing price emphasis oriented to quality and quantity (Limaj \& Bernroider, 2019). Rajapathirana and Hui (2018) have a research entitled "Relationship between innovation capability, innovation type, and firm performance."

Rajapathirana and Hui (2018) revealed that the success factor for business innovation is taken from several essential aspects, namely: Innovation capability, Innovation type, Innovation Performance, Market Performance, and Financial performance. Where the measurement of market innovation (market innovation) is based on the fulfillment of aspects of promotion and promotion techniques in technology-based media, as well as the placement of online salespeople to monitor sales movements (Rajapathirana \& Hui, 2018). The next aspect suggested by Rajapathirana and Hui (2018) is the development of original products, increasing the value of authentic products by adding features to the original product.

A study by Distanont \& Khongmalai (2018) entitled 'The Role of Innovation in creating a competitive advantage', put forward the concept of competitive advantage with three main dimensions, namely, superior efficiency, superior quality, and customer responsiveness. Where, from the aspect of superior efficiency, Distanont and Khongmalai (2018) state measurement indicators such as 1) the efficient use of the budget illustrated through the selection of appropriate technology to cut costs, and 2) the ability of business people to obtain products directly through a short distribution process. Distanont and Khongmalai, (2018b) also provide measurement through improvement in superior quality as a means of creating competitive advantage: 1) Business ability in presenting quality products at competitive prices, 2). And the ability of a business organization to provide access to fast and responsible shipping. As well as the responsibility to customers and the environment (CSR) also includes efforts to create competitive advantage (Murdifin et al., 2018).

Business strategy is an essential point in wading through competition and even innovation itself, including procedures in increasing competition. Elrehail (2018), in his study with the competitive advantage theory approach and the RBV, shows that there is a positive and significant relationship between entrepreneurship, innovation, and business strategy.
Kubíčková, Votoupalová, and Toulová, (2014) state that there is a significant relationship between entrepreneurship on the application of innovation and performance. More complex in studies than Kubíčková, Votoupalová, and Toulová, (2014), it is emphasized that business strategy is the company's efforts to take policies and guidelines that have integrated commitments and actions and are designed to build excellence in business competition to meet and achieve business goals. Lorenzo, Rubio, and Garcés (2018) stated that in business strategy, managerial capability is an essential aspect of the organization. Lorenzo et al., (2018) also said indicators rather than managerial accessibility include the ability of a businessman to have a clear business vision, the ability of a businessman to establish excellent communication with his customers, and the ability of a businessman to achieve a predetermined target. Added by (Lorenzo et al., 2018), this reveals that business strategy means prioritizing the quality of products and services through a balance and suitability between the products offered and the products provided to consumers.

Lorenzo et al. (2018) also stressed the importance of using technology to facilitate consumers' ordering and payment process, which is the right step to start a competitive business strategy. Excellent service, fast, and responsive to every customer complaint is also the key to success in building an adequate business strategy. About the RBV, Lorenzo et al. (2018) say that the ability of business organizations represented by capable employees in using technology and understanding the rules of business is a valuable asset to increase competition.

\section{Research Design and Method}

\subsection{Samples Criteria}

This study involved 497 samples from online food SME actors who used Go-Jek online transportation facilitation as their business media. Determination of sample criteria was based on the total number of online food SMEs with community assessment score criteria 4-5 (with star rating). We only make samples for online food SME products on GoFood, whose production activities are food products made from rice, vegetables, and side dishes such as meat and fish or SMEs in the category of Indonesian food products.

\subsection{Materials and Measurement}

This study was conducted in Makassar City in the mid2019 - early-2020 period. Some of the research material came from primary surveys. The survey contains 28 questions (see Appendix 5) each assessed using a 7-point Likert scale (1 $=$ Strongly disagree, 2 = Disagree, 3 = Moderately disagree, 4 $=$ Neutral, $5=$ Moderate agree, $6=$ Agree, and $7=$ Strongly 


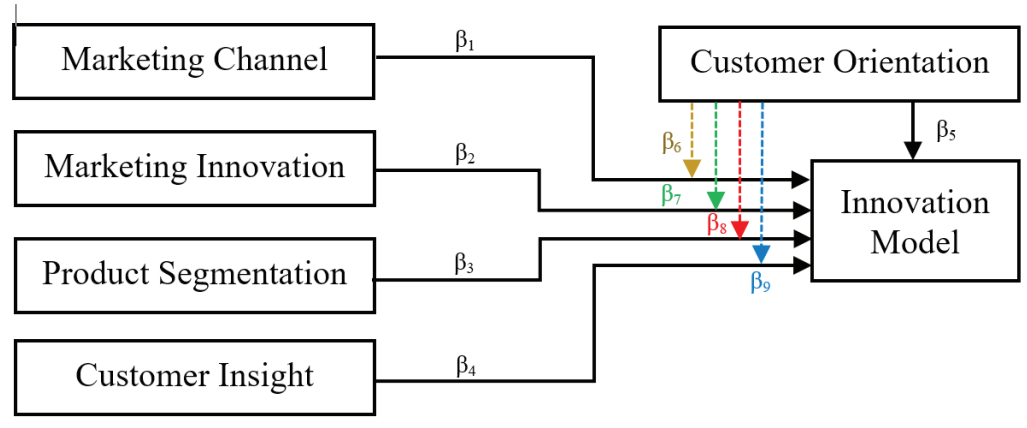

Figure 1: Step one, Re-Conceptualization of Innovation

agree). Considering this study model is a development model, the standard measurement of the feasibility of the variable model is based on the results of the study (Chin, 1998) where the standard measurement of AVE, Cronbach's Alpha and composite reliability (CR) is a minimum of 0.50 , while in some literature, especially regarding the use of Partial Least Square (PLS), the value of AVE, Cronbach's Alpha and CR is a minimum of 0.60 (Hair et al., 2017; Hair, Gabriel, \& Patel, 2014). While other assessment standards, such as significance testing, still refer to the consensus of statistics with a $5 \%$ error margin, Normality $>0.50$, and VIF $<10$.

This study, through three analysis scenarios, namely, scenario I, is a re-conceptualization of innovation modeling that is moderated by customer satisfaction variables, as in Figure 1.

The scenario $I$ in Figure 1 is to present a reconceptualization model of the innovation model with moderating customer orientation variables. Then, in scenario II, the Innovation model becomes an independent variable to measure the effect and relationship of the business strategy variable (Intervening variable) to the competitive advantage variable (dependent variable), as shown in Figure 2.

The approach to solving the research formulation in this study uses explorative quantitative through several stages of testing, including the outlier test to determine biased sample criteria, the normality test using the Kolmogorov-Smirnov method with the Asymptotic approach obtained in the SPSS software. We are testing the validity of the Discriminant Validity approach and reliability testing with the Cronbach's Alpha approach and Average Variance Extract. Overall testing in this study involves Smart-PLS as an analysis test tool. By testing two stages, namely, the algorithm stage to measure the pre-test and the feasibility of the model, as well as the bootstrapping test with a constant bootstrapping mode to test and predict the model.

Scenario III is a comprehensive path analysis of a conceptual structure with an approach based on directrelations, intervening, and moderation. The direct relationship between

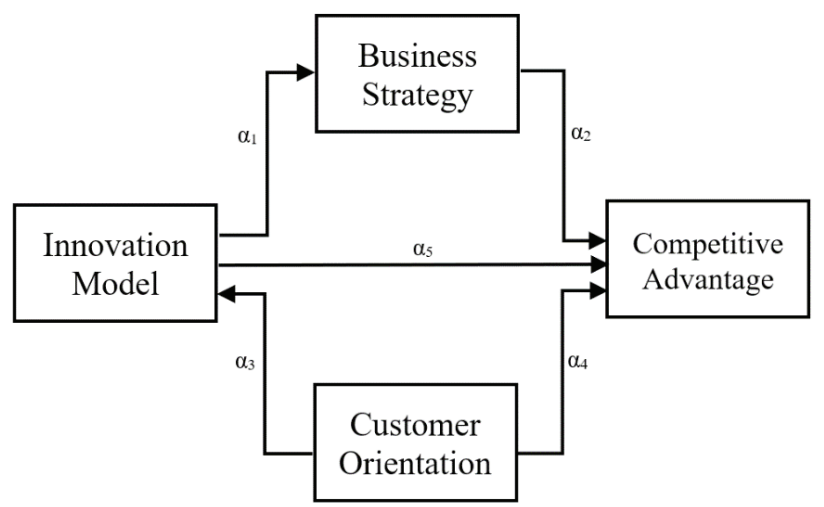

Figure 2: Step two, Direct and Intervening Variable Relationship

variables involves marketing channel variables (Independent var. 1), Marketing innovation variables (Independent var. 2), Product Segmentation (Independent var. 3), and Customer Insights (Independent var. 4) to Competitive advantage as dependent variables consisting of Superior Efficiency (construct dependent variable. 1), Superior quality (construct dependent variable. 2), and Responsibility to customers (construct dependent variable.3). It was then moderated by the Customer Orientation Variable (moderating variable). While the intervening variable is the business strategy. In detail, the conceptual framework of this study is explained in Appendix 1 in the form of a PLS statistical presentation.

\section{Results and Discussion}

\subsection{Statistical Analysis}

\subsubsection{Scenario I}

The scenario I in the analysis of this study is in Figure 1. The analysis of the re-conceptualization model of the 
innovation model shows that each outer loading value $(>0.60)$, both in the construct manifest and in the moderation of the customer orientation. So, the external loading value states that all items and construct indicators in building innovation variables are suitable and feasible. Furthermore, testing the validity by looking at the value of discriminant validity and Average Variance Extracted (AVE) also show it is viable and suitable and met the assumptions of previous studies of PLS pre-requisite tests such as Chin (1998), which says that the development model for the lowest value for AVE is 0.50 . Beside that, reliability testing or indicator reliability testing in compiling variable elements by looking at Cronbach's Alpha values and Composite Reliability values, vulnerable at $0.763-0.941$, shows that indicators and construct items in manifesting a variable are very reliable. Then, the multicollinearity test using the VIF method in this study states that the entire construct is also feasible with a VIF value $<10$. Illustration about the importance of each test in this first stage is presented as in Appendix 2.

\subsubsection{Scenario II}

As illustrated in Figure 2 and or Appendix 3, it explains direct testing and intervening in a model to analyze the roles and relationships of the innovation model reconceptualization of various dependent variables. Like testing scenario I, scenario II also passes the model feasibility test by analyzing the validity, reliability through the algorithm process in PLS and testing the effect through the constant bootstrapping process. The explanation of the second stage of testing is illustrated in Appendix 3. In the explanation of discriminant validity (see Appendix 3), it illustrates that each item is related to one another. The linkages are also in the close range to the very close relevance of validity. For example, the causality that explains the construct Marketing Innovation (MI) on customer insight (CI), which is 0.722 or $72.2 \%$, (MI on $\mathrm{Co}=0.682$ or $68.2 \%$ ), (MI on $\mathrm{IM}=$ 0.874 or $87.4 \%$ ), ( $\mathrm{MI}$ on $\mathrm{MC}=0.780$ or $78 \%$ ) and so on as described in the discriminant validity column. In conclusion, statistically, with a significance rule $<0.05$, it can be stated that all items are perfect for modifying the latest innovation model as outlined in this study. Apart from that, the role of items/constructs that are based on and controlled by customer orientation variables provide an essential part as the primary manifestation in developing innovation or in other words that Marketing Channel (MC), Marketing Innovation (MI), Product Segmentation (PS), Customer Insight (PS) CI) must be based on the urgency of Customer Orientation (CO).

\subsubsection{Scenario III}

The relationship between variables through direct effects (see Appendix 4) illustrates that all paths of analysis (path $\alpha$ and $\beta$ ) are significant. Referring to Figure 2, which explains the relationship between variables, it demonstrates the relationship between the innovation model on Business Strategy (BS), which is reflected in the $\alpha 1$ analysis path showing the most dominant relationship value and effect $(\mathrm{t}$-stats $=41.038)$. Likewise, with all paths of analysis, $\alpha 2$ to $\alpha 5$ also showed a positive and significant relationship.

Item construction of the innovation model variable (e.g., marketing channel, marketing innovation, product segmentation, customer insight) as forming the innovation model (IM) variable as illustrated in Figure 1 with the $\beta 1$ through $\beta 4$ analysis path, it also represents a significant and positive situation, especially in the $\beta 4$ analysis path that customer insight items have the most dominant influence $(\mathrm{t}$-stats $=41.803)$.

Furthermore, it still refers to the results in Figure 2 , namely, in the case of moderation relationships. The Customer Orientation (CO) variable in manifesting the innovation model depicted in Appendix 4 in the moderating effect column is only one path of analysis that is not significant, the $\beta 7$ analysis path. While the path of study with the moderation relationship that is the path of analysis $\beta 6, \beta 8, \beta 9$ has a positive and significant effect. Statistically, it can be concluded that the path of analysis, which is insignificant through the moderation relationship depicted through the $\beta 7$ way of summary, namely, moderation of the customer orientation on the marketing innovation variable, is not mutually influential.

In connection with scenario III involving a specific indirect/intervening relationship, it was found that the $\mu 5$ analysis pathway did not have a significant effect (sig level = $0.55<0.05)$. In contrast, the other fifteen analysis pathways had a substantial and positive impact. With the PLS modeling, there are sixteen lines of indirect analysis, which are broadly divided into six lines of investigation based on the dependent variable. Such as direct effect relationships that place Customer Insight items as the dependent variable (Analysis path $\mu 1$ to $\mu 3$ ), Customer orientation items (Analysis path $\mu 4$ to $\mu 6$ ), Marketing Channel items (Analysis path $\mu 7$ to $\mu 9$ ), Marketing innovation item (Analysis path $\mu 10$ through $\mu 12$ ), Product segmentation item (way of analysis $\mu 13$ to $\mu 15)$, the path of analysis of the main variables, namely, innovation model (IM) to competitive advantage (CA) with the moderation of business strategy (BS) on the path of analysis $\mu 16$ also shows significant and positive effects and causality.

\subsection{Discussion}

The innovation model developed in this study involving items (e.g., marketing channel, marketing innovation, product segmentation, and customer insight) turned out to provide concrete evidence that the combination of these 
items can produce positive and significant results. Marketing channel means using all the potential marketing channels available, both conventional and digital. Today's businessrelated marketing-channel innovations require business people to no more extend focus on traditional channels (e.g., make old-time face-to-face sales, focus on beautifying store conditions as was common in the past).

However, business people must also be able to see the potential of marketing by making digital sales on e-commerce channels. Of course, the various advantages and disadvantages of selling conventionally versus selling digitally must be identified. The ease of marketing products digitally means removing absurd boundaries and market segmentation, and this is undoubtedly good news for the business world today, where everyone has the potential to become a marketer without having to possess substantial assets or tangible fixed assets in the form of land, stores, building like a conventional marketing model in the past. Of course, the use of digital channels as the necessary foundation of innovation today, must also take into account various factors (e.g., the ability of human resources to use technology, capital adequacy factors to provide technological devices, as well as core-business models, whether the business owned is time to use technology or not). Not all business characters are required to use digital marketing channels, and a business person must be clean and rational in measuring the growth potential of his business, especially the products to be sold and who are his main customers.

Re-conceptualization of marketing innovations developed in this study emphasizes the aspect of education to potential consumers. This means that in various situations and educational positions, the question is to provide clear and accurate information to consumers, help consumers to make choices that are considered appropriate, and provide ideal references and preferences to consumers. Given the size of a business, naturally a substantial profit is worthless without planning for future sustainability. Education and preferences conducted by a marketer to prospective customers will undoubtedly provide positive values, such as a good impression or positive personal branding. Therefore, giving ideal choices and education to potential consumers, a businessman/marketer must also have the mastery and insight of a product. They are reviewing business/sales/ targeted sales issues, incomplete without discussing and understanding the desires of consumers and market trends.

The movement of consumer behavior that continues to experience dynamic changes gives a warning to business people and marketers to keep trying to be customer-oriented. The knowledge possessed by business people/marketers about consumer behavior, customer insights, and the psychology of customers and markets is undoubtedly a manifestation for creating a sustainable business in competition. The empirical model that combines moderating customer orientation variables provides evidence that innovation must rely on customer orientation.

\section{Conclusions}

The service-dominant logic (SD Logic) theory approach is described by Lusch et al. (2007). This study provides an important affirmation that supporting business success, business continuity, industry orientation, and business people must be centered on the service needs of customers. This study also contributes to scientific management in the field of strategy about Resource-Based View (RBV) Theory, where aspects of surpassing competition do not only rely on the maximum utilization of resources. With the combination of service-dominant logic towards RBV, the form of service to consumers is a type of responsibility to customers, such as the accuracy and speed of business managers in providing services, as well as internal business expertise in providing explanations (preferences) to consumers. Therefore, the relationship between service-dominant logic (Lusch et al., 2007) and RBV (Lewis, 1981; Porter \& Advantage, 1985; Brouthers \& Brouthers, 1997; Barney, 1991) is very close and interrelated so that the prediction of business innovation models in the future based on the needs of customers is that innovation is much needed. Apart from that, the development model on this innovation variable is proven to be able to be part of, or complete, the existing innovation model construct.

\section{References}

Abdelaal, M. S. (2019). Biophilic campus: An emerging planning approach for a sustainable innovation-conducive university. Journal of Cleaner Production, 215(April), 1445-1456. https:// doi.org/10.1016/j.jclepro.2019.01.185

Abdolmaleki, K., \& Ahmadian, S. (2016). The Relationship between Product Characteristics, Customer and Supplier Involvement, and New Product Development. Procedia Economics and Finance, 36(16), 147-156. https://doi.org/10.1016/S22125671(16)30026-0

Agarwal, M. K., \& Goodstadt, B. E. (1997). Gaining a competitive advantage in the U.S. wireless telephony market: The marketing challenge. Telematics and Informatics, 14(2), 159-171. https:// doi.org/10.1016/S0736-5853(96)00031-7

Alam, R., Hamzah, N., Putra, A. H. P. K., Ginting, W. A., \& Teng, S. H. (2019). What Is More Important In Business? The Fallacy In Interpreting Innovation As a Strategy. 1st International Conference on Life, Innovation, Change and Knowledge (ICLICK 2018). https://doi.org/10.2991/iclick-18.2019.59

Alpkan, L., Şanal, M., \& Ayden, Y. (2012). Market Orientation, Ambidexterity and Performance Outcomes. Procedia Social and Behavioral Sciences, 41, 461-468. https://doi. org/10.1016/j.sbspro.2012.04.056 
Annarelli, A., Battistella, C., \& Nonino, F. (2020). Competitive advantage implication of different Product Service System business models: Consequences of 'not-replicable' capabilities. Journal of Cleaner Production, 247(February), 119121. https:// doi.org/10.1016/j.jclepro.2019.119121

Aujirpongpan, S., \& Hareebin, Y. (2020). The Effect of Strategic Intuition, Business Analytic, Networking Capabilities and Dynamic Strategy on Innovation Performance: The Empirical Study Thai Processed Food Exporters. Journal of Asian Finance, Economics and Business, 7(1), 259-268. https://doi. org/10.13106/jafeb.2020.vol7.no1.259

Barney, J. (1991). Firm Resources and Sustained Competitive Advantage. Journal of Management, 17(March), 99-120. https://doi.org/10.1177/014920639101700108

Brouthers, K. D., \& Brouthers, L. E. (1997). Explaining national competitive advantage for a small European country: A test of three competing models. International Business Review, 6(1), 53-70. https://doi.org/10.1016/S0969-5931(96)00036-4

Chin, W. (1998). The partial least squares approach to structural equation modeling. Modern Methods for Business Research, 295(2), 295-336. https://doi.org/10.1016/j.aap.2008.12.010

Chiu, S.-H., \& Lin, T.-Y. (2019). Evaluation of Regional Knowledge Innovation System in China: An Economic Framework Based on Dynamic Slacks-based Approach. Journal of Asian Finance, Economics and Business, 6(3), 141-149. https://doi. org/10.13106/jafeb.2019.vol6.no3.141

Chung, L., \& Tan, K. H. (2017). The unique Chinese innovation pathways: Lessons from Chinese small- and medium-sized manufacturing firms. International Journal of Production Economics, 190(August), 80-87. https://doi.org/10.1016/j. ijpe.2016.09.004

Dahliah, D., Kurniawan, A., \& Putra, A. H. P. K. (2020). Analysis and Strategy of Economic Development Policy for SMEs in Indonesia. The Journal of Asian Finance, Economics and Business, 7(5), 103-110. https://doi.org/10.13106/jafeb.2020. vol7.no5.103

D’Este, P., Amara, N., \& Olmos-Peñuela, J. (2016). Fostering novelty while reducing failure: Balancing the twin challenges of product innovation. Technological Forecasting and Social Change, 113(Part B December), 280-292. https://doi. org/10.1016/j.techfore.2015.08.011

De Silva, M., Al-Tabbaa, O., \& Khan, Z. (2019). Business model innovation by international social purpose organizations: The role of dynamic capabilities. Journal of Business Research, (Article In Press). https://doi.org/10.1016/j.jbusres.2019.12.030

Distanont, A., \& Khongmalai, O. (2018a). The role of innovation in creating a competitive advantage. Kasetsart Journal of Social Sciences, 41(1). 1-7. https://doi.org/10.1016/j.kjss.2018.07.009

Distanont, A., \& Khongmalai, O. (2018b). The role of innovation in creating a competitive advantage. Kasetsart Journal of Social Sciences. https://doi.org/10.1016/j.kjss.2018.07.009

Elrehail, H. (2018). The relationship among leadership, innovation and knowledge sharing: A guidance for analysis. Data in
Brief, 19 (August), 128-133. https://doi.org/10.1016/j. dib.2018.04.138

Felício, J. A., Caldeirinha, V., \& Dutra, A. (2019). Ambidextrous capacity in small and medium-sized enterprises. Journal of Business Research, 101(February), 607-614. https://doi. org/10.1016/j.jbusres.2019.02.061

Firman, A., Mustapa, Z., Ilyas, G. B., \& Putra, A. H. P. K. (2020). Relationship of TQM on managerial perfomance: Evidence from property sector in Indonesia. In Journal of Distribution Science (Vol. 18, Issue 1, pp. 47-57). https://doi.org/10.15722/ jds.18.01.20201.47

Giao, H. N. K. (2020). Customer Satisfaction at Tiki.vn E-Commerce Platform. Journal of Asian Finance, Economics and Business, 7(4), 173-183. https://doi.org/10.13106/jafeb.2020.vol7.no4.173

Grover, S., Agrawal, V. P., \& Khan. (2004). A digraph approach to TQM evaluation of an industry. International Journal of Production Research, 42(19), 4031-4053. https://doi.org/10.1 080/00207540410001704032

Hair, J. F., Gabriel, M. L. D. da S., \& Patel, V. K. (2014). AMOS Covariance-Based Structural Equation Modeling (CB-SEM): Guidelines on its Application as a Marketing Research Tool. Revista Brasileira de Marketing, 13(2). https://doi.org/10.5585/ remark.v13i2.2718

Hair, J. F., Hult, G. T. M., Ringle, C. M., \& Sarstedt, M. (2017). A Primer on Partial Least Squares Structural Equation Modeling (PLS-SEM) (2nd Edition). Thousand Oaks, CA: Sage Publications, Inc.

Halim Perdana Kusuma, A., Kadir, A., Muis, M., Nurhilalia, \& Jusni. (2019). Determinant of Market Orientation on SME Performance: RBV and SCP Perspective. Journal of Distribution Science, 17(9), 34-45. https://doi.org/10.15722/ jds.17.09.201909.35

Haming, M., Syaiful, A. Z., Putra, A. H. P. K., \& Murdifin, I. (2019). The Application of \{SERVQUAL\} Distribution In Measuring Customer Satisfaction of Retails Company. Journal of Distribution Science, 17(2), 25-31. https://doi.org/10.15722/ jds.17.2.201902.25

Ho, K. L. P., Nguyen, C. N., Adhikari, R., Miles, M. P., \& Bonney, L. (2017). Exploring market orientation, innovation, and financial performance in agricultural value chains in emerging economies. Journal of Innovation \& Knowledge, 3(3), 154163. https://doi.org/10.1016/j.jik.2017.03.008

Indahingwati, A., Launtu, A., Tamsah, H., Firman, A., Putra, A. H. P. K., \& Aswari, A. (2019). How Digital Technology Driven Millennial Consumer Behaviour in Indonesia. Journal of Distribution Science, 17(8), 25-34. http://dx.doi.org/10.15722/ jds.17.08.201908.25

Ioanid, A., Deselnicu, D. C., \& Militaru, G. (2018). The impact of social networks on SMEs' innovation potential. Procedia Manufacturing, 22, 936-941. https://doi.org/10.1016/j. promfg.2018.03.133

Kubíčková,L., Votoupalová, M., \& Toulová, M. (2014). Key Motives for Internationalization Process of Small and Medium-Sized 
Enterprises. Procedia Economics and Finance, 12(March), 319-328. https://doi.org/10.1016/S2212-5671(14)00351-7

Le, H. B. H., \& Le, T. B. (2020). Impact of Destination Image and Satisfaction on Tourist Loyalty: Mountain Destinations in Thanh Hoa Province, Vietnam. Journal of Asian Finance, Economics and Business, 7(4), 185-195. https://doi. org/10.13106/jafeb.2020.vol7.no4.185

Leigh, D. (2010). SWOT Analysis. In Handbook of Improving Performance in the Workplace. Chapter 5. Willey Online Library. https://doi.org/10.1002/9780470587102.ch5

Lewis, W. (1981). Competitive strategy, Michael E. Porter, The Free Press, New York, 1980. No. of pages: 396. Strategic Management Journal, 2(1), 93-95. https://doi.org/10.1002/ smj.4250020110

Limaj, E., \& Bernroider, E. W. N. (2019). The roles of absorptive capacity and cultural balance for exploratory and exploitative innovation in SMEs. Journal of Business Research, 94(September), 137-153. https://doi.org/10.1016/j. jbusres.2017.10.052

Liu, Y., Jiang, C., \& Zhao, H. (2019). Assessing product competitive advantages from the perspective of customers by mining user-generated content on social media. Decision Support Systems, 123(August), 113079. https://doi.org/10.1016/j. dss.2019.113079

Lorenzo, J. R. F., Rubio, M. T. M., \& Garcés, S. A. (2018). The competitive advantage in business, capabilities and strategy. What general performance factors are found in the Spanish wine industry? Wine Economics and Policy, 7(2), 94-108. https://doi.org/10.1016/j.wep.2018.04.001

Lusch, R. F., Vargo, S. L., \& O’brien, M. (2007). Competing through service: Insights from service-dominant logic. Journal of Retailing, 83(1), 5-18. https://doi.org/10.1016/j. jretai.2006.10.002

Mashur, R., Gunawan, B. I., Ashoer, M., Hidayat, M., Perdana, H., \& Putra, K. (2019). Moving From Traditional to Society 5.0: Case study by Online Transportation Business. Journal Distribution Science, 17(9), 93-102. http://dx.doi. org/10.15722/jds.17.09.201909.93

Mashur, R., Muhammad, H., Ansir, L., AHP, K. P. A. H. P., \& Shandra, B. (2020). Antecedents and consequence of brand management: empirical study of Apple's brand product. In Journal of Asia Business Studies: Vol. ahead-of-p (Issue aheadof-print). https://doi.org/10.1108/JABS-01-2019-0030

Mappamiring, M., Akob, M., \& Putra, A. H. P. K. (2020). What Millennial Workers Want? Turnover or Intention to Stay in Company. The Journal of Asian Finance, Economics and Business, 7(5), 237-248. https://doi.org/10.13106/jafeb.2020.vol7.no5.237

Merdika, D., Sule, T., Kartini, D., Oesman, M., Halim Perdana Kusuma, A., Putra, K., \& Chamidah, N. (2019). Moderating of the Role of Technology Theory to the Existence of Consumer Behavior on e-commerce. Journal of Distribution Science, 17(7), 15-25. https://doi.org/10.15722/jds.17.07.201907.15

Murdifin, I., Pelu, M. F. A. R., Putra, A. A. H. P. K., Arumbarkah, A. M., Muslim, M., \& Rahmah, A. (2018). Environmental Disclosure as Corporate Social Responsibility: Evidence from the Biggest Nickel Mining in Indonesia. International Journal of Energy Economics and Policy, 9(1), 115-122.

Porter, M. E., \& Advantage, C. (1985). Creating and sustaining superior performance. Competitive Advantage. New York, NY: Free Press, 167.

Putra, A. H. P. K., Haming, M., Murdifin, I., Zulfikar Syaiful, A., \& Aditya, H. P. K. P. (2019). The Application of SERVQUAL Distribution In Measuring Customer Satisfaction of Retails Company. Journal of Distribution Science, 17(2), 25. https:// doi.org/10.15722/jds.17.02.201902.25

Raja, M. W., \& Wei, S. (2014). TQM Practices and Innovation Performance : A Review of Current Literature. British Journal of Economics, Management \& Trade, 4(7), 1018-1032.

Rajapathirana, R. P. J., \& Hui, Y. (2018). Journal of Innovation. Suma de Negocios, 3(1), 44-55. https://doi.org/10.1016/j.jik.2017.06.002

Roberts, R. (1998). Managing innovation: The pursuit of competitive advantage and the design of innovation intense environments. Research Policy, 27(2), 159-175. https://doi. org/10.1016/S0048-7333(98)00034-1

Rodríguez, R., Molina-Castillo, F.-J., \& Svensson, G. (2020). The mediating role of organizational complexity between enterprise resource planning and business model innovation. Industrial Marketing Management, 84(January), 328-341. https://doi. org/10.1016/j.indmarman.2019.09.007

Ruiz-Ortega, M. J., Parra-Requena, G., García-Villaverde, P. M., \& Rodrigo-Alarcon, J. (2017). How does the closure of interorganizational relationships affect entrepreneurial orientation? BRQ Business Research Quarterly, 20(3), 178-191. https://doi. org/10.1016/j.brq.2017.04.003

Tran, V. D., Vo, T. N. L., \& Dinh, T. Q. (2020). The Relationship between Brand Authenticity, Brand Equity and Customer Satisfaction. Journal of Asian Finance, Economics and Business, 7(4), 213-221. https://doi.org/10.13106/jafeb.2020. vol7.no4.213

Vila, O. R., Bharadwaj, S. G., \& Bahadir, S. C. (2015). Explorationand Exploitation-Oriented Marketing Strategies and Sales Growth in Emerging Markets. Customer Needs and Solutions, 2(4), 277-289. https://doi.org/10.1007/s40547-015-0053-0

Yusuf, M., \& Putra, A. H. P. K. (2019). The Impact of Product Quality, Price, and Distribution on Satisfaction and Loyalty. Journal of Distribution Science, 17, 17-26. 


\section{Appendix}

Appendix 1: Step Three, Path Analysis \& Conceptual Framework

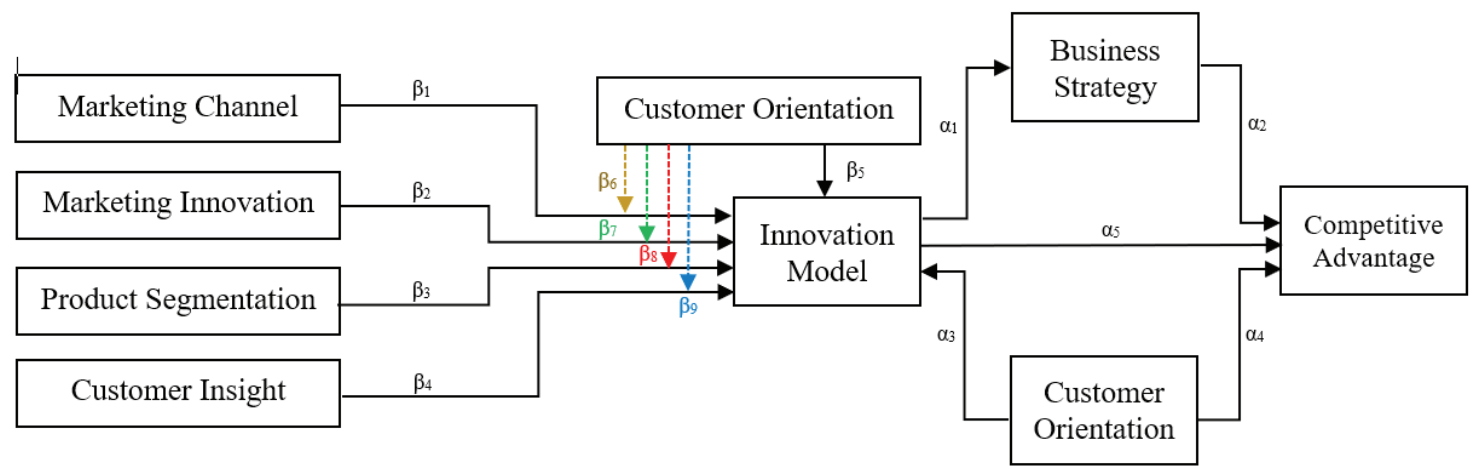

Appendix 2: Testing Feasibility Model Scenario I

\begin{tabular}{|c|c|c|c|c|c|c|c|}
\hline Variables & Item & Construct & Outer Loading & $\begin{array}{c}\text { Cronbach's } \\
\text { Alpha }\end{array}$ & rho_A & C.R & AVE \\
\hline \multirow{13}{*}{$\begin{array}{l}\text { Conceptualization of } \\
\text { Innovation }\end{array}$} & Marketing Channel & Mc1 & 0.845 & \multirow{4}{*}{0.846} & \multirow{4}{*}{0.846} & \multirow{4}{*}{0.896} & \multirow{4}{*}{0.684} \\
\hline & & Mc2 & 0.843 & & & & \\
\hline & & Mc3 & 0.827 & & & & \\
\hline & & Mc4 & 0.793 & & & & \\
\hline & Marketing Innovation & $\operatorname{Im} 1$ & 0.864 & \multirow{3}{*}{0.763} & \multirow{3}{*}{0.760} & \multirow{3}{*}{0.864} & \multirow{3}{*}{0.679} \\
\hline & & $\mathrm{Im} 2$ & 0.840 & & & & \\
\hline & & $\operatorname{Im} 3$ & 0.765 & & & & \\
\hline & Product Segmentation & Ps1 & 1.000 & 1.000 & 1.000 & 1.000 & 1.000 \\
\hline & Customer Insight & $\mathrm{Ci} 1$ & 0.864 & \multirow{5}{*}{0.931} & \multirow{5}{*}{0.930} & \multirow{5}{*}{0.947} & \multirow{5}{*}{0.781} \\
\hline & & $\mathrm{Ci} 2$ & 0.922 & & & & \\
\hline & & $\mathrm{Ci} 3$ & 0.895 & & & & \\
\hline & & $\mathrm{Ci} 4$ & 0.902 & & & & \\
\hline & & $\mathrm{Ci} 5$ & 0.835 & & & & \\
\hline \multirow{7}{*}{\multicolumn{2}{|c|}{$\begin{array}{l}\text { Customer orientation } \\
\text { (intervening variable) }\end{array}$}} & Co1 & 0.902 & \multirow{3}{*}{0.787} & \multirow{3}{*}{0.819} & \multirow{3}{*}{0.877} & \multirow{3}{*}{0.708} \\
\hline & & $\mathrm{Co} 2$ & 0.911 & & & & \\
\hline & & Co3 & 0.792 & & & & \\
\hline & & Mod-c1 & \multirow{4}{*}{1.000} & \multirow{4}{*}{1.000} & \multirow{4}{*}{1.000} & \multirow{4}{*}{1.000} & \multirow{4}{*}{1.000} \\
\hline & & Mod-mc & & & & & \\
\hline & & Mod-ps & & & & & \\
\hline & & Mod-mi & & & & & \\
\hline \multicolumn{8}{|l|}{ Discriminant Validity } \\
\hline & C.I & C.O & I.M & M.C & \multicolumn{2}{|c|}{ M.I } & P.S \\
\hline Customer Insight & 0.884 & & & & & & \\
\hline Customer Orientation & 0.753 & 0.841 & & & & & \\
\hline Innovation Model & 0.939 & 0.789 & 0.767 & & & & \\
\hline Marketing Channel & 0.689 & 0.689 & 0.873 & 0.827 & & & \\
\hline Marketing Innovation & 0.722 & 0.682 & 0.874 & 0.780 & 0.8 & & \\
\hline Product Segmentation & 0.793 & 0.569 & 0.769 & 0.519 & 0.5 & & 1.000 \\
\hline
\end{tabular}


Appendix 3: Testing Feasibility Model Scenario II

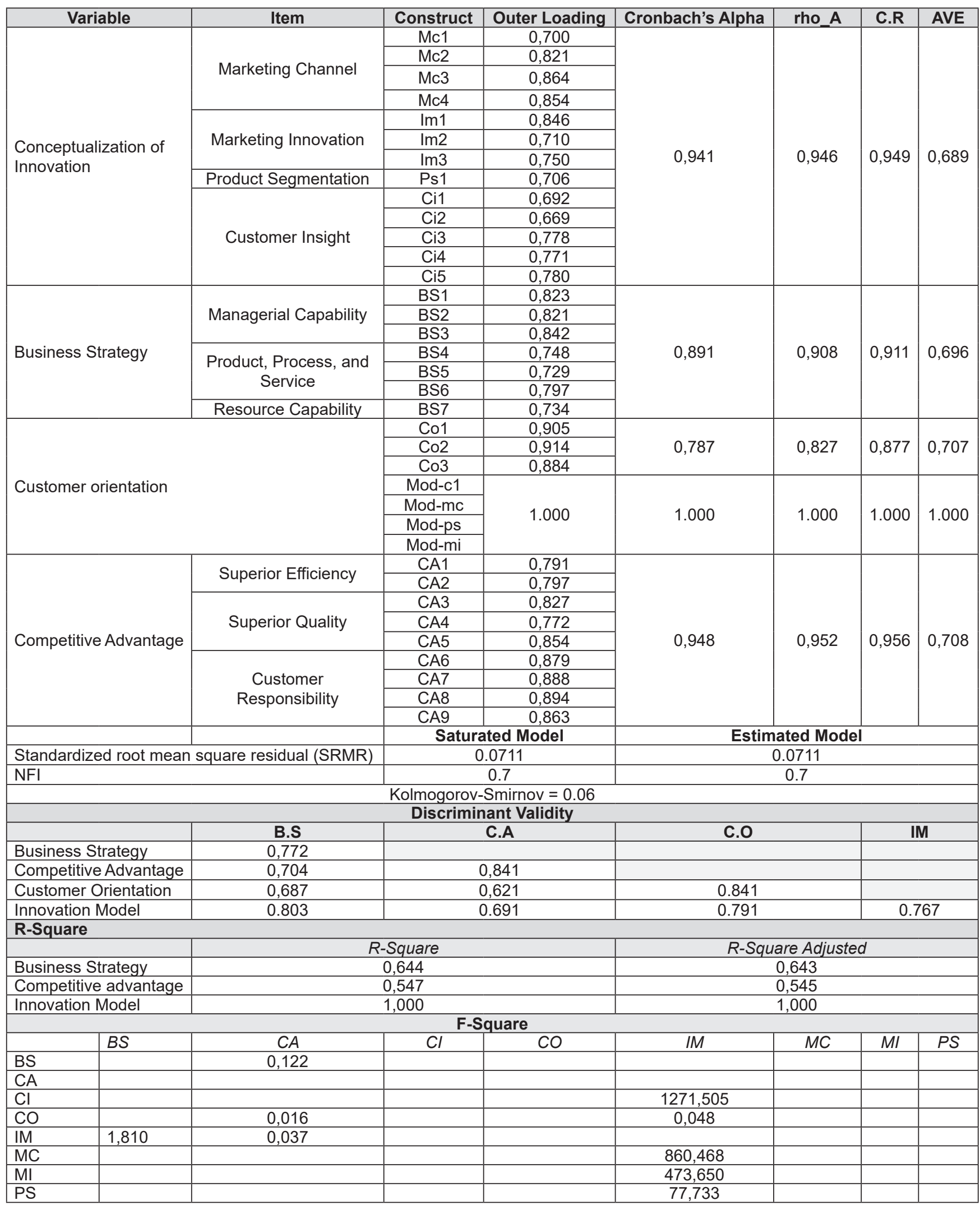


Appendix 4: Path Analysis

\begin{tabular}{|c|c|c|c|c|c|c|}
\hline \multicolumn{7}{|c|}{ Direct Effect } \\
\hline \multicolumn{2}{|r|}{ Path Analysis } & \multirow{2}{*}{$\begin{array}{c}\begin{array}{c}\text { Sample } \\
\text { Mean } \\
\text { (M) }\end{array} \\
0,804 \\
\end{array}$} & \multirow{2}{*}{$\begin{array}{c}\begin{array}{c}\text { Standard } \\
\text { Deviation } \\
\text { (STDEV) }\end{array} \\
0,020 \\
\end{array}$} & \multirow{2}{*}{$\begin{array}{c}\begin{array}{c}\text { T Statistics } \\
\text { (|O/STDEV|) }\end{array} \\
41,038\end{array}$} & \multirow{2}{*}{$\begin{array}{c}\begin{array}{c}\mathbf{P} \\
\text { Values }\end{array} \\
0,000 \\
\end{array}$} & \multirow{2}{*}{$\begin{array}{c}\text { Info } \\
\text { Support }\end{array}$} \\
\hline$\alpha 1$ & Innovation Model $\rightarrow$ Business Strategy & & & & & \\
\hline$\alpha 2$ & Business Strategy $\rightarrow$ Competitive advantage & 0,394 & 0,079 & 5,062 & 0,000 & Support \\
\hline a3 & Customer Orientation $\rightarrow$ Innovation Model & 0,002 & 0,001 & 2,589 & 0,010 & Support \\
\hline$a 4$ & Customer Orientation $\rightarrow$ Competitive advantage & 0,140 & 0,061 & 2,346 & 0,019 & Support \\
\hline a5 & Innovation Model $\rightarrow$ Competitive advantage & 0,265 & 0,091 & 2,845 & 0,005 & Support \\
\hline$\beta 1$ & Marketing Channel $\rightarrow$ Innovation Model & 0,297 & 0,008 & 36,266 & 0,000 & Support \\
\hline$\beta 2$ & Marketing Innovation $\rightarrow$ Innovation Model & 0,226 & 0,007 & 31,979 & 0,000 & Support \\
\hline$\beta 3$ & Product Segmentation $\rightarrow$ Innovation Model & 0,097 & 0,004 & 24,854 & 0,000 & Support \\
\hline$\beta 4$ & Customer Insight $\rightarrow$ Innovation Model & 0,496 & 0,012 & 41,803 & 0,000 & Support \\
\hline \multicolumn{2}{|r|}{ Path Analysis } & $\begin{array}{c}\text { Sample } \\
\text { Mean } \\
\text { (M) }\end{array}$ & $\begin{array}{l}\text { Standard } \\
\text { Deviation } \\
\text { (STDEV) } \\
\end{array}$ & $\begin{array}{l}\text { T Statistics } \\
\text { (|O/STDEV|) }\end{array}$ & $\begin{array}{c}\text { P } \\
\text { Values }\end{array}$ & Info \\
\hline$\beta 6$ & mod-mc $\rightarrow$ Innovation Model & 0,001 & 0,001 & 1,899 & 0,049 & Support \\
\hline$\beta 7$ & mod_mi $\rightarrow$ Innovation Model & 0,000 & 0,001 & 0,316 & 0,752 & Not Support \\
\hline$\beta 8$ & mod-ps $\rightarrow$ Innovation Model & 0,002 & 0,001 & 2,378 & 0,018 & Support \\
\hline$\beta 9$ & mod-ci $\rightarrow$ Innovation Model & 0,002 & 0,001 & 1,983 & 0,018 & Support \\
\hline \multicolumn{2}{|r|}{ Path Analysis } & $\begin{array}{c}\text { Sample } \\
\text { Mean } \\
\text { (M) }\end{array}$ & $\begin{array}{l}\text { Standard } \\
\text { Deviation } \\
\text { (STDEV) }\end{array}$ & $\begin{array}{c}\text { T Statistics } \\
\text { (|O/STDEV|) }\end{array}$ & $\begin{array}{c}\text { P } \\
\text { Values }\end{array}$ & Info \\
\hline$\mu 1$ & Customer Insight $\rightarrow$ Innovation Model $\rightarrow$ Business Strategy & 0,399 & 0,012 & 31,945 & 0,000 & Support \\
\hline$\mu 2$ & $\begin{array}{l}\text { Customer Insight } \rightarrow \text { Innovation Model } \rightarrow \text { Business Strategy } \\
\rightarrow \text { Competitive advantage }\end{array}$ & 0,157 & 0,031 & 5,071 & 0,000 & Support \\
\hline$\mu 3$ & $\begin{array}{l}\text { Customer Insight } \rightarrow \text { Innovation Model } \rightarrow \text { Competitive } \\
\text { advantage }\end{array}$ & 0,132 & 0,045 & 2,845 & 0,005 & Support \\
\hline$\mu 4$ & $\begin{array}{l}\text { Customer Orientation } \rightarrow \text { Innovation Model } \rightarrow \text { Business } \\
\text { Strategy }\end{array}$ & 0,002 & 0,001 & 2,646 & 0,008 & Support \\
\hline$\mu 5$ & $\begin{array}{l}\text { Customer Orientation } \rightarrow \text { Innovation Model } \rightarrow \text { Competitive } \\
\text { advantage }\end{array}$ & 0,001 & 0,000 & 1,927 & 0,055 & Not Support \\
\hline$\mu 6$ & $\begin{array}{l}\text { Customer Orientation } \rightarrow \text { Innovation Model } \rightarrow \text { Business } \\
\text { Strategy } \rightarrow \text { Competitive advantage }\end{array}$ & 0,001 & 0,000 & 2,279 & 0,023 & Support \\
\hline$\mu 7$ & $\begin{array}{l}\text { Marketing Channel } \rightarrow \text { Innovation Model } \rightarrow \text { Business } \\
\text { Strategy }\end{array}$ & 0,239 & 0,008 & 28,212 & 0,000 & Support \\
\hline$\mu 8$ & $\begin{array}{l}\text { Marketing Channel } \rightarrow \text { Innovation Model } \rightarrow \text { Competitive } \\
\text { advantage }\end{array}$ & 0,079 & 0,027 & 2,824 & 0,005 & Support \\
\hline$\mu 9$ & $\begin{array}{l}\text { Marketing Channel } \rightarrow \text { Innovation Model } \rightarrow \text { Business } \\
\text { Strategy } \rightarrow \text { Competitive advantage }\end{array}$ & 0,094 & 0,018 & 5,128 & 0,000 & Support \\
\hline$\mu 10$ & $\begin{array}{l}\text { Marketing Innovation } \rightarrow \text { Innovation Model } \rightarrow \text { Business } \\
\text { Strategy } \rightarrow \text { Competitive advantage }\end{array}$ & 0,072 & 0,014 & 5,041 & 0,000 & Support \\
\hline$\mu 11$ & $\begin{array}{l}\text { Marketing Innovation } \rightarrow \text { Innovation Model } \rightarrow \text { Business } \\
\text { Strategy }\end{array}$ & 0,182 & 0,007 & 27,388 & 0,000 & Support \\
\hline$\mu 12$ & $\begin{array}{l}\text { Marketing Innovation } \rightarrow \text { Innovation Model } \rightarrow \text { Competitive } \\
\text { advantage }\end{array}$ & 0,060 & 0,021 & 2,845 & 0,005 & Support \\
\hline$\mu 13$ & $\begin{array}{l}\text { Product Segmentation } \rightarrow \text { Innovation Model } \rightarrow \text { Business } \\
\text { Strategy } \rightarrow \text { Competitive advantage }\end{array}$ & 0,031 & 0,006 & 5,010 & 0,000 & Support \\
\hline$\mu 14$ & $\begin{array}{l}\text { Product Segmentation } \rightarrow \text { Innovation Model } \rightarrow \text { Competitive } \\
\text { advantage }\end{array}$ & 0,026 & 0,009 & 2,793 & 0,005 & Support \\
\hline$\mu 15$ & $\begin{array}{l}\text { Product Segmentation } \rightarrow \text { Innovation Model } \rightarrow \text { Business } \\
\text { Strategy }\end{array}$ & 0,078 & 0,004 & 20,476 & 0,000 & Support \\
\hline$\mu 16$ & $\begin{array}{l}\text { Innovation Model } \rightarrow \text { Business Strategy } \rightarrow \text { Competitive } \\
\text { advantage }\end{array}$ & 0,317 & 0,062 & 5,115 & 0,000 & Support \\
\hline
\end{tabular}


Appendix 5: Measurement of Variable

\begin{tabular}{|c|c|c|}
\hline Variables & Item & Construct \\
\hline \multirow{4}{*}{$\begin{array}{l}\text { Reconceptualization } \\
\text { Model Innovation }\end{array}$} & $\begin{array}{l}\text { Marketing } \\
\text { channel }\end{array}$ & $\begin{array}{l}\text { 1. Business capabilities using e-commerce sales access } \\
\text { 2. Repeat advertising } \\
\text { 3. The ability of businesses to use social media access as a marketing and } \\
\text { promotional media } \\
\text { 4. The use of endorser figures to be more convincing of the products being } \\
\text { marketed }\end{array}$ \\
\hline & $\begin{array}{l}\text { Marketing } \\
\text { Innovation }\end{array}$ & $\begin{array}{l}\text { 5. The ability of entrepreneurs and internal business in mastering the marketed } \\
\text { product } \\
\text { 6. Conduct periodic evaluations of marketed products } \\
\text { 7. Companies not only carry out marketing activities but also provide education } \\
\text { to customers }\end{array}$ \\
\hline & $\begin{array}{l}\text { Product } \\
\text { Segmentation }\end{array}$ & $\begin{array}{l}\text { 8. Products that are marketed clearly in specific segments that include age, } \\
\text { gender and income level }\end{array}$ \\
\hline & $\begin{array}{l}\text { Customer } \\
\text { Insights }\end{array}$ & $\begin{array}{l}\text { 9. Business-Oriented development by the times } \\
\text { 10. Business Oriented to the protection and security of user data } \\
\text { 11. Business Oriented to the selection of the best raw materials } \\
\text { 12. Business Oriented to reasonable quality control before selling on the market } \\
\text { 13. Business Oriented to excellent service and after-sales that do not complicate } \\
\text { consumers }\end{array}$ \\
\hline \multirow{3}{*}{ Business Strategy } & $\begin{array}{l}\text { Managerial } \\
\text { Capability }\end{array}$ & $\begin{array}{l}\text { 14. Company Have a clear business mission vision } \\
\text { 15. The ability to establish excellent communication with customers } \\
\text { 16. Ability to reach the specified target }\end{array}$ \\
\hline & $\begin{array}{l}\text { Products, } \\
\text { Processes, and } \\
\text { Services }\end{array}$ & $\begin{array}{l}\text { 17. Conformity between the products offered and the products provided to } \\
\text { consumers } \\
\text { 18. Utilization of technology to facilitate consumers in the process of ordering } \\
\text { and payment of goods purchased } \\
\text { 19. Excellent service, friendly and responsive to every customer complaint }\end{array}$ \\
\hline & $\begin{array}{l}\text { Resource } \\
\text { Capability }\end{array}$ & $\begin{array}{l}\text { 20. The ability of a business that has qualified employees to use the latest } \\
\text { technology to facilitate marketing access }\end{array}$ \\
\hline \multicolumn{2}{|l|}{ Customer Orientation } & $\begin{array}{l}\text { 21. Meeting customer-based production needs } \\
\text { 22. A good relationship with the customer } \\
\text { 23. Excellent service pre-selling and after selling }\end{array}$ \\
\hline \multirow{3}{*}{$\begin{array}{l}\text { Competitive } \\
\text { advantage }\end{array}$} & $\begin{array}{l}\text { Superior } \\
\text { efficiency }\end{array}$ & $\begin{array}{l}\text { 24. The use of an efficient budget that is illustrated through the selection of } \\
\text { appropriate technology to cut variable costs } \\
\text { 25. Business ability in acquiring products to be marketed directly from the source } \\
\text { (industry) }\end{array}$ \\
\hline & Superior quality & $\begin{array}{l}\text { 26. The ability of SME businesses in presenting quality products at competitive } \\
\text { prices } \\
\text { 27. The strength of SME businesses to provide faster and responsible delivery } \\
\text { access } \\
\text { 28. Products marketed have excellent durability }\end{array}$ \\
\hline & $\begin{array}{l}\text { Customer } \\
\text { Responsibility }\end{array}$ & $\begin{array}{l}\text { 29. The accuracy and speed of SMEs in providing services through easy and } \\
\text { up-to-date communication access } \\
\text { 30. SME's internal business expertise in providing detailed explanations of } \\
\text { products marketed to consumers } \\
\text { 31. Ease of consumers in finding, paying and tracking every transaction that } \\
\text { they have done } \\
\text { 32. Provision of more trusted e-commerce accounts for consumers in terms of } \\
\text { transactions }\end{array}$ \\
\hline
\end{tabular}

